\title{
Postsekularyzm jako wędrujące pojęcie. Wprowadzenie
}

„Modus vivendi secundum virtutem” to znana każdemu uczestnikowi późnych wykładów Stanisława Pietraszki - twórcy wrocławskiego kulturoznawstwa definicja kultury. Odtwarza ona formułę św. Alberta Wielkiego, dominikanina i nauczyciela św. Tomasza z Akwinu. Definicja ta, tłumaczona jako „sposób życia podług wartości”, jest podstawowa w aksjologicznie zorientowanej teorii kultury Pietraszki. Co ciekawe, wykładowca ten, jak wynika ze wspomnień jego uczniów, nigdy nie przywoływał religijnego kontekstu tej definicji. Podobnie jak religia nie stanowiła pierwszoplanowego tematu jego naukowych dociekan, a przecież w kontekście europejskim trudno mówić o aksjologii, pomijając jej religijne konotacje. Być może więc rację mają ci, którzy wskazują na teologiczną ś 1 e p ą $\mathrm{p} l \mathrm{a} \mathrm{m} \mathrm{kę} \mathrm{(theology} \mathrm{blind} \mathrm{spot)} \mathrm{nauk} \mathrm{społecznych} \mathrm{i} \mathrm{humanistycznych} \mathrm{XX} \mathrm{w.?}{ }^{1}$

„Powrót religii” — jako tematu rozważań w obrębie różnych dyscyplin humanistyki i nauk społecznych — jaki dokonuje się szczególnie intensywnie przez ostatnie dwie dekady, zarówno sprzyja identyfikacji wspomnianego strukturalnego „niewidzenia”, jak i czyni zasadnym ponowienie pytań o sposób istnienia religii w kulturze i społeczeństwie, jej obecną kulturowo-społeczną kondycję oraz religijne korzenie i charakter wielu kategorii nauk o człowieku i jego świecie, łącznie z pojęciem kultury².

Wspomniany powrót problematyki religijnej spełnia się pod różnymi imionami: „powrót sacrum” (Daniel Bell), „powrót bogów” (Friedrich-Wilhelm Graf), „zemsta Boga” (Gilles Kepel) oraz „postsekularyzm”. To właśnie ten ostatni termin jest szczególnie popularny, semantycznie pojemny, niejednoznaczny i będący nie tylko poznawczym wyzwaniem ${ }^{3}$. Nie ma zgody co do źródeł i rodowodu myśli postsekularnej. Postsekularyzm wywodzony bywa z myśli romantycznej, kojarzony z modernizmem lub szkołą frankfurcką. W niniejszym tomie odnosimy się

${ }^{1} \mathrm{http} / / /$ blogs.ssrc.org/tif/2014/02/13/the-theology-blind-spot/.

${ }^{2} \mathrm{~K} \mathrm{u} 1 \mathrm{t} \mathrm{u} \mathrm{r}$ a bywa traktowana jako pojęcie zawierające przemieszczone sakralne treści, wskazuje się także na analogię głębokiej logiki kultury i religii, por. np. D. LaCapra, Historia w okresie przejściowym. Doświadczenie, tożsamość, teoria krytyczna, Kraków 2009; P. Kuligowski, Rozprawa z Odysem. Trzy szkice z humanistyki integralnej, Wrocław 2017.

${ }^{3} \mathrm{~W}$ złożoność i bogactwo wątków problematyki postsekularyzmu daje bardzo dobry wgląd wydana w Polsce w 2012 roku antologia Drzewo poznania. Postsekularyzm w przektadach i komentarzach. Pracę zredagowali Piotr Bogalecki i Alina Mitek-Dziemby, wstęp do niej napisał Tadeusz Sławek, a posłowiem opatrzyła Agata Bielik-Robson. 
do współczesnych zagadnień związanych z kulturowym i społecznym sposobem istnienia wiary i niewiary, nie sięgając głębiej w przeszłość niż do tradycji szkoły frankfurckiej, której dziedzicem jest Jürgen Habermas — współczesny promotor podejścia postsekularnego. Nota bene Agata Bielik-Robson Dialektykę oświecenia Adorna i Horkheimera nazywa ,pierwszym świadomym dziełem postsekularnym, poddającym krytycznemu namysłowi płytką świeckość zachodniego oświecenia"4. Filozofka opowiada się za tezą, że nowoczesność określa nie tyle spór rozumu z wiarą, ile podskórne zderzenie, konflikt dwóch typów sakralnej wrażliwości. Religijność grecka według autorki orientuje się na m i t, domkniętą wizję bytu. Sacrum w takim rozumieniu ma charakter immanentny. W przeciwieństwie do tego z kolei religijność żydowska i chrześcijańska kieruje się ku w y j ś c i u, przezwyciężaniu wszystkiego, co zastane, jest to sacrum transcendentne. Bielik-Robson pozwala w kategorii postsekularyzmu dostrzec być może to, co w niej najciekawsze - nie przekreślając zmiany sposobu istnienia religii w świecie współczesnym, problematyzuje ona pojęcia, które do niedawna kojarzyły nam się wyłącznie świecko, z pojęciem rozumu na czele.

Pośród różnych sposobów traktowania problematyki postsekularyzmu można wyróżnić: jego ujęcie jako projektu politycznego współistnienia wierzących i niewierzących (to idea bliska ujęciu Habermasowskiemu); rekonfigurację myśli filozoficznej ${ }^{5}$; metodyczną próbę rewizji refleksji nad kulturą przez pryzmat religii, bliską temu, co za Doris Bachmann-Medick można by określić mianem kolejnego zwrotu, choć autorka o postsekularyzmie pisze jedynie w kontekście zwrotu translacyjnego:

Nauki o kulturze, które pierwotnie same startowały jako projekt modernizacyjny, stają teraz przed zadaniem krytyki następstw kulturowej modernizacji, sekularyzacji i racjonalizacji, jakie wywierają wpływ na dzisiejsze społeczeństwa europejskie i stanowią dla nich wyzwanie. W tym kontekście Habermas w każdym razie obok osi neurobiologicznej przedstawił koncepcję drugiej głównej osi filozoficzno-politycznej refleksji: zastanawiające ponowne wkroczenie religijności do ,post-laickich społeczeństw”. Tworzenie kulturoznawczej teorii powinno być na to szczególnie uwrażliwione. W społeczeństwach „post-laickich” chodzi bowiem o to, by ,istotne treści przetłumaczyć z języka religijnego na język powszechnie zrozumiały". A przy tym religijne przekonania i manifestacje wiary powinny być przez świeckie państwo i świecką konstytucję

${ }^{4}$ A. Bielik-Robson, Powrót mesjańskiej obietnic, czyli postsekularyzm w sensie ścistym, [w:] Deus otiosus. Nowoczesność w perspektywie postsekularnej, red. A. Bielik-Robson, M. Sosnowski, Warszawa 2013, s. 338.

${ }^{5}$ Z filozoficznych dyskusji w polskiej literaturze sprawę zdają między innymi cytowane Drzewo poznania oraz Deus otiosus, natomiast wiele ważnych prac przetłumaczono na język polski: Religia: seminarium na Capri prowadzone przez Jacques'a Derridę i Gianniego Vattimo, w którym udziat wzięli Maurizio Ferraris [et al.] (tłum. różni, Warszawa 1999); T. Eagelton, Rozum, wiara i rewolucja. Refleksje nad debata o Bogu (przeł. W. Usakiewicz, Kraków 2010); A. Badiou, Święty Paweł. Ustanowienie uniwersalizmu (przeł. J. Kutyła. P. Mościcki, Kraków 2007). Znak drukował przekład tekstu jednego z fundatorów Radykalnej Ortodoksji J. Milbanka, Tajemnica rozumu (Znak 2010, nr 7-8). Warto pamiętać o dużo wcześniejszej książce na temat kryzysu wyobraźni religijnej — Ziemi Ulro Czesława Miłosza (Paryż 1977). 
podporządkowane ,instytucjonalnym ograniczeniom przekładu”, pod którymi dopiero mogą one uzyskać dostęp do powszechnie akceptowanego języka. Post-laickie społeczeństwa wyróżniają się tym, że z jednej strony obstają przy rozdzieleniu wiary i wiedzy, a z drugiej strony uwzględniają żywione przez wspólnoty wiary prawomocne roszczenia i społecznie niezbywalne wyobrażenia wartościujące, zamiast je odsunąć na bok, jak nakazywałby bez reszty zsekularyzowany i scjentystycznie zredukowany rozum. Jednakże niezbędne tu publiczne stosowanie rozumu w „dialogu społecznym” wymaga, aby jednostronność ,instytucjonalnego ograniczania przekładu” uzupełniano „kooperacyjnymi dokonaniami przekładowymi ${ }^{6}$.

Można wreszcie uznać, i to ujęcie jest najbliższe zamysłowi tego tomu, p o s t s e k u l a r y z m za jedno z ,wędrujących pojęć” humanistyki, które — choć bez wspólnego teoretycznego mianownika - wskazuje na tendencję do ponownego podejmowania tematyki religii w kilku polach badawczych, od socjologii, przez teorię polityki, literaturoznawstwo, kulturoznawstwo, po filozofię.

Podejmując problem postsekularyzmu, trzeba uwzględnić także sekularyzm i jego dwa zasadnicze rozumienia. Według pierwszego sekularyzm to ideologia/ światopogląd, który zakłada wyższość postawy niereligijnej wobec religijnej, w kategoriach politycznych oznacza to zazwyczaj dążenie do wyłączenia religii ze sfery politycznej i publicznej, a w obrębie filozofii poznawczą waloryzację immanencji. Drugie — szersze rozumienie - wiąże sekularyzm z kwestiami relacji między sferą religijną i świecką. Znamienna dlań może być charakterystyka świeckości w ujęciu Charlesa Taylora ${ }^{7}$. Epoka świecka to, według tego kanadyjskiego filozofa, epoka, w której religia przestaje być domyślnym składnikiem sposobu widzenia świata, a staje się jedynie jedną z możliwych opcji.

W świetle owego rozróżnienia postsekularyzm jawi się jako przekroczenie pierwszego — węższego — rozumienia sekularyzmu. Nie ma bowiem dostatecznych podstaw, by zakwestionować świeckość współczesnego zachodniego świata. Religia w dalszym ciągu jest tu kwestią wyboru. Postsekularyzm, najlapidarniej rzecz ujmując, uwrażliwia poznawczo i politycznie zarówno na przemienioną obecność religii, jak i dokonywane jej świadome oraz nieświadome wykluczenia.

Choć atrakcyjność kategorii postsekularyzmu może być ograniczona przez zmniejszającą się żywotność wąsko rozumianego sekularyzmu (którego śmierć może być ogłoszona przedwcześnie - jak sugeruje zamieszczony w tym tomie szkic Tomasza Sieczkowskiego), to nie ma wątpliwości, że jest to kategoria, która zdecydowanie otworzyła humanistykę i nauki społeczne na nowe sposoby widzenia znaczenia religii, dychotomii wiary i niewiary, pozwoliła pełniej ująć egzystencję — zmuszając badaczy ludzkiego uniwersum do ponownego zmierzenia się z kategoriami immanencji i transcendencji oraz pokazując, że dychotomia śmierci Boga i jego bezwarunkowego powrotu to uproszczenie.

${ }^{6}$ D. Bachmann-Medick, Cultural Turns. Nowe orientacje w naukach o kulturze, przeł. K. Krzemieniowa, Warszawa 2012, s. 462. Problem relacji między teologią a naukami społecznymi w epistemologicznym aspekcie przedstawia Elżbieta Hałas w tekście Między odrzuceniem religii a zbawieniem świata: itineraria socjologii i postsekularnej teorii społecznej (,Stan Rzeczy” 2013, nr 5).

${ }^{7}$ Ch. Taylor, Secular Age, Cambridge, Mass. 2007. 
Pytanie o kulturę postsekularną, zawarte w tytule niniejszego tomu „Prac Kulturoznawczych", jest zachętą do namysłu zarówno nad kwestiami współczesnej kulturowej kondycji religii, jak i religijnej kondycji kultury. Olivier Roy, politolog, jeden z najwybitniejszych francuskich ekspertów w sprawach islamu, w rozmowie otwierającej ten tom podtrzymuje swą, wcześniej wyłożoną w Holy Ignorance i zapewne prowokującą dla kulturoznawców, tezę o powolnym rozchodzeniu się dróg religii i kultury. Przejawia się to — jak twierdzi — w tendencji do zastępowania wartości normami, a dokładniej rzecz ujmując - w coraz powszechniejszej kodyfikacji różnych dziedzin naszego życia, stanowiącej reakcję na brak czy zaburzenia kulturowej „nawigacji”. Kodyfikacja, której Roy zamierza poświęcić swą kolejną książkę, to właśnie w jego ujęciu dekulturacja religii (i odpowiednio - paradoksalna dekulturacja kultury). Pojawia się tu interesująca dla badaczy kultury sugestia politologa, by kwestię relacji kultury i religii badać w analizie współczesnych aksjotycznych fenomenów.

Roy z dystansem odnosi się do rozpowszechnionego za sprawą Jürgena Habermasa pojęcia postsekularyzmu, przeciwny jest bowiem sprowadzaniu sekularyzmu wyłącznie do antyreligijnej ideologii i łączeniu go en bloc z radykalną tezą o zaniku religii. Nadal zdaniem Roy żyjemy w świeckiej Europie (wyjątki mają potwierdzać regułę), w której dokonały się głębokie zmiany w sferze religii, natomiast nie - jej niwelacja czy eliminacja. Obecny „powrót sacrum” i ponowna „widoczność” religii traktowane są przez niego jako element sekularnego pejzażu, a nawet rezultat sekularyzmu. Taką sugestię zawierał także raport o znaczeniu religii w świeckiej Europie, którego Roy był naukowym koordynatorem ${ }^{8}$. Podkreślano w nim, że to sekularyzacja kultury przyczyniła się do wykroczenia dyskusji o religii poza kwestie konfliktu Kościoła i państwa, a tym samym poza problem władzy, ku zagadnieniom teologicznym, filozoficznym i kulturoznawczym. Konfrontacja z islamem zintensyfikowała dyskusję o znaczeniu chrześcijaństwa w Europie, które jest dziś przez wielu chrześcijan traktowane głównie jako tożsamość, a nie wiara, co samo w sobie — zdaniem Roy — jest potwierdzeniem zwycięstwa sekularyzacji.

Harald Wydra, antropolog polityki z Uniwersytetu w Cambridge, autor książki Polityka i sakralność (2015) - publikujemy jej wstęp w polskim tłumaczeniu — traktuje tytułowe fenomeny jako „bliźniacze siły” i zaznacza, że nie są one definiowane $\mathrm{z}$ wykorzystaniem relacji podporządkowania. W swej charakterystyce sacrum autor podkreśla zarówno jego poliwalentność, transformującą moc, jak i historyczną przygodność jego manifestacji. Polityczność interesuje go w jej doświadczeniowym i wpólnotowym wymiarze jako aktywne poszukiwanie

${ }^{8}$ Rethinking the Place of Religion in European Secularized Societies: The Need For More Open Societies. Conclusions of the Research Project ReligioWest, European University Institute, March 2016, http://cadmus.eui.eu/bitstream/handle/1814/40305/RSCAS_Research_Project_Conclusion.. pdf?sequence $=3 \&$ is Allowed $=\mathrm{y}$. 
znaczenia. Autor konstatuje, że sakralności można doświadczać na różne sposoby. Religia stanowi jakkolwiek fundamentalny, lecz nie jedyny nośnik sacrum, a epoka sekularna nie jest całkiem wyzbyta pragnienia przekroczenia immanencji. Po Wielkiej Rewolucji Francuskiej, przypomina Wydra, sacrum przesunęło się ze sfery politycznej władzy ku kulturalnym praktykom, etycznym imperatywom i powojennym upamiętnieniom. Uwagę autora skupiają przede wszystkim doświadczenia i sytuacje graniczne w ich aspekcie genealogicznym. Jako „słabe momenty", pęknięcia - a nie binarne opozycje - uwalniają siły generujące wartości, idee, prawdy. Żyjemy w epoce „poofiarniczej”, ale sacrum nie jest przeżytkiem, nieustająco ma wpływ na kształtowanie tożsamości politycznych wspólnot i ich poczucia egzystencjalnego bezpieczeństwa.

Michał Matlak przedmiotem rozważań czyni niejednorodny charakter europejskiego sekularyzmu, wskazuje na jego odmienne historyczne i intelektualne źródła, zróżnicowanie powiązanych z nim ujęć religii i jej funkcji, rozmaitość towarzyszących mu postaw oraz programów politycznych. Autor, podobnie jak Roy, nie traktuje sekularyzmu jako alternatywy religii, stąd pośród trzech jego podstawowych form, prezentowanych w tekście, znajduje się sekularyzm chrześcijański, mający swe najodleglejsze korzenie w średniowieczu, w napięciach między papiestwem a cesarstwem. Obszerna charakterystyka sekularyzmu chrześcijańskiego obejmuje jego dwa warianty — konserwatywny, dla którego formującym wydarzeniem stała się Wielka Rewolucja Francuska, i chrześcijańsko-demokratyczny, ukształtowany przez Sobór Watykański II. Pozostałe dwie formy to laicyzm i agnostycyzm. Ufundowany głównie na francuskiej myśli oświeceniowej i legitymowany francuską ustawą o rozdziale Kościoła i państwa z grudnia 1905 r., laicyzm ma także dwa swoje oblicza - antyreligijne i republikańskie. Wojna trzydziestoletnia i kończący ją pokój westfalski wskazane zostały jako historyczne źródło kolejnej sekularnej formy, kształtującej się w okresie dziewiętnastowiecznych wojen kulturowych i inspirowanej głównie myślą anglosaską — liberalny agnostycyzm. Współczesna forma liberalnego agnostycyzmu z tendencją do depolityzacji religii znajduje wyraz i uzasadnienie w myśli Johna Rawlsa. Ta historyczno-politologiczna panorama sekularyzmu, jego złożonego charakteru komplikuje tym samym obraz postsekularyzmu i pokazuje ograniczenia tej kategorii w koncepcji Habermasa.

Tomasz Wiśniewski zauważa, że jakkolwiek problematyka postsekularna jest obecna w wielu akademickich dyscyplinach, to nie ma bogatej reprezentacji w historii, stąd jego szkicowa propozycja konceptualizacji postsekularyzmu czy raczej postsekularnego przełomu w kontekście historycznej wiedzy i dziejowej zmiany. $\mathrm{Z}$ inspiracji Haydena White'a autor sięga do kategorii wydarzenia w jego ontologicznym rozumieniu i traktuje go jako radykalny akt, w wyniku którego dochodzi do podważenia i demaskacji „fałszywej świadomości” oraz zmian w wyobraźni społecznej. Istnieje nieredukowalne napięcie między wydarzeniem a jego dyskursywną, teoretyczną artykulacją. Jako przykłady wydarzeń postsekularnych autor wskazał zamach terrorystyczny z 11 września 2001 r. i rewolucję irańską z 1978 r. Istotną cechą 
zwrotu postsekularnego według autora jest jego przyszłościowa orientacja i w tym kontekście pojawia się koncepcja Anandy Abeysekary („opłakiwania sekularnej przyszłości”) oraz Uległość Houllebecqa jako (anty-?)utopia realizująca postsekularny scenariusz.

Jak wiadomo, spory o religię nigdy nie sprowadzają się do sporów światopoglądowych. Jednak w rozważaniach o kulturowym statusie religii komponenta światopoglądowa, zwłaszcza gdy w wartościach upatruje się legitymację poglądu na świat, jest trudna do pominięcia. Dotyczy to także światopoglądu ateistycznego, który bez wątpienia jest elementem postsekularnego krajobrazu i podobnie jak agnostycyzm podlega dziś pogłębionej refleksji, co ma ustrzec przed naiwną, tradycjonalną, nawykową niewiarą. Tomasz Sieczkowski, jakkolwiek sugeruje, że można ująć ateizm jako ruch kulturowy, to rozważa go przede wszystkim właśnie w wymiarze światopoglądowym. Autor nie nawiązuje do głośnych na początku XX w. ruchu wolnomyślicielskiego i walki o kulturę świecką, lecz koncentruje się na współczesności. Orędownicy interesującego go nowego ateizmu, Daniel Dennett, Anthony Clifford Grayling, Christopher Hitchens, Richard Dawkins, są pełni rezerwy wobec idei postsekularnych głoszonych przez takich myślicieli, jak Habermas. Najogólniej rzecz ujmując, nowi ateiści proklamację postsekularyzmu uważają za przedwczesną. Sieczkowski, podkreślając, że światopogląd nie jest ideologią, nauką czy filozofią, nie pomija jego poznawczego wymiaru, akcentuje zawierającą się w światopoglądzie dyspozycję do działania i zwraca uwagę na instytucjonalną jego bazę. Nowy ateizm według autora zorganizowany jest wokół dwóch osi — pozytywnej (nawiązania do tradycji sekularnych Zachodu, głównie w kwestiach rozpoznania rzeczywistości politycznej) oraz negatywnej (aktywny opór wobec wartości religijnych w życiu publicznym). Sieczkowski wylicza rozmaite strategie i szczegółowe taktyki, w których wyraża się antagonizm wobec religii (konfrontacja, agresja, demitologizacja, demistyfikacja). Autor sygnalizuje również problem niespójności nowoateistycznego ruchu oraz istnienie sporów w jego obrębie, co warte byłoby zdecydowanie dalszych, pogłębionych badań. Ateizm i powiązane z nim wąskie rozumienie sekularyzmu dodają jednak sensowności kategorii postsekularyzmu, która odsłania jego paradoksalnie religijny charakter, co widać w pracach dużej części autorów prezentowanych przez Sieczkowskiego.

Ewa Tak-Ignaczak rozważa społeczno-kulturową kondycję religii, analizując literacki sukces trzech współczesnych holenderskich pisarzy różnych generacji Maartena 't Harta, Frank Treura i Jana Siebelinka — rozliczających się z dziedzictwem chrześcijańskim w postaci ortodoksyjnego kalwinizmu. Autorka, budując kontekst tej analizy, przypomina historyczny podział Holandii na katolickie południe i protestancką północ, istnienie pasa biblijnego (ortodoksyjnego kalwinizmu) oraz tak zwaną filaryzację — specyficzny społeczno-kulturowy porządek obowiązujący od XIX w., w którym upatruje się zarówno podstaw tolerancji religijnej, jak i źródła problemów z jednoznacznym określeniem holenderskiej narodowej tożsamości. Filary (protestancki, katolicki i humanistyczny w wersji liberalnej oraz 
socjalistycznej) przesądzające o światopoglądzie, edukacji, a nawet upodobaniach estetycznych, wpływały na sposób życia i podziały w obrębie holenderskiego społeczeństwa, których społeczno-kulturowe echo do dziś jest żywo obecne. Współcześnie Holandia ma opinię jednego z najbardziej zsekularyzowanych krajów Zachodu, w którym światopogląd ateistyczny i agnostycyzm przybierają masowy charakter. Blisko milionowa społeczność muzułmańska tam mieszkająca staje się tym samym szczególnym - nie tylko politycznym — wyzwaniem. Twórczość, w znacznej mierze autobiograficzna, pisarzy przywołanych w tekście to niezwykle cenne literackie świadectwo złożoności procesów sekularyzacyjnych (jak to ujmuje autorka, od jawnej wrogości wobec religii przez nostalgię do fascynacji mistyką łaski). Oto dzięki literaturze mamy poznawczy dostęp do zanikających i emancypujących się wspólnot religijnych, które ze względu na swą hermetyczność rzadko stają się przedmiotem systematycznego badania. Dotykamy tu także dzięki ekspresji literackej tego, co zyskało miano deprywatyzacji niewiary.

Syberia w tekście Izoldy Topp jawi się jako miejsce swoistego eksperymentu in vivo. Po blisko siedemdziesięciu latach prób ateizacji i eliminacji religii z życia społecznego (przebiegających z różną skutecznością i intensywnością oraz wiążących się, co przypomina autorka, z przemocą zarówno symboliczną, jak i fizyczną), mamy do czynienia $\mathrm{z}$ fenomenem ,powrotu religii”. W tytule artykułu zawiera się pewna diagnoza nieoczywistości tego powrotu. Mianowicie, mowa jest o „religiach wynalezionych”, co jest nawiązaniem do koncepcji tradycji wynalezionych Erica Hobsbawma. Społeczno-polityczna transformacja, skutki ateizacji, egzystencjalne konsekwencje kryzysu ekonomicznego, dyskusyjny status światopoglądu religijnego, brak ciągłości wspólnot religijnych, etniczno-tożsamościowa i polityczna instrumentalizacja religii — to czynniki, które problematyzują jej status i czynią przedmiotem negocjacji formę jej ponownej obecności. Autorka szczególną uwagą obdarzyła jedną z rdzennych religii Syberii — szamanizm buriacki. Okazał się on wyjątkowo dobrym przykładem tego, że nie sposób mówić o ,powrocie religii”, pomijając transformacje, jakim ona w różnych wymiarach swego społecznego i kulturowego istnienia podlega.

Jeszcze jednym przykładem zakwestionowania podziałów i klisz symplifikujących złożoność kwestii postsekularyzmu jest tekst Joanny Sierackiej. Podjęła ona problem relacji feminizmu i Kościoła katolickiego w Polsce, do czego impulsem stała się książka Zuzanny Radzik Kościót kobiet, zawierająca bliski autorce, choć zgłaszany z innych pozycji światopoglądowych, postulat dekonstrukcji opozycji Kościół-feminizm. Sieracka, deklarująca się jako świecka feministka, zauważa niefortunność strategii podsycania konfliktu, redukowania feminizmu do antyklerykalizmu, ruchu antykościelnego (współmyśli tu między innymi z Agnieszką Graff oraz Moniką Bobako) i nie podziela założenia wielu świeckich feministek o wyłącznie opresyjnym charakterze Kościoła katolickiego wobec kobiet. Zgadza się bowiem z przekonaniem, że zrównanie życia religijnego z opresją i wiktymizacją wspiera $\mathrm{w}$ istocie radykalnie antyfeministyczną politykę Kościoła. Ignorowanie re- 
ligijnej afiliacji to désintéressement dla egzystencjalnego wymiaru życia wielu kobiet, sfery nie tylko manifestacji przekonań, lecz także artykulacji wartości, a więc wymiaru kulturowego istnienia. Dystans, jaki feministki, zwłaszcza prezentujące postawę konstruktywistyczną, mają do wartości dowodowej doświadczenia (por. Joan Scott), powinien być, zdaniem autorki, uchylony na tyle, by nie zgubić istotnej w tym kontekście perspektywy egzystencjalistycznej. Zawarta w tekście analiza feministycznej debaty, eksponująca tematykę walki o prawa rozrodcze, kościelnej kampanii antygenderowej i sporów o demokrację ujęta została jako przejaw paradygmatu sekularyzująco-modernistycznego, któremu towarzyszy przekonanie o niewspółmierności walki o prawa kobiet i misji Kościoła. Autorka zaleca porzucenie tej perspektywy, podobnie jak zerwanie z feministyczną polityką tożsamości. Jako strategię przyszłości proponuje strategię troski, która obejmie także kobiety w Kościele, i zapobiegnie pogłębianiu się wrogiej polaryzacji społecznej debaty.

Dawid Junke analizuje z kolei relacje między popkulturą a procesami sekularyzacyjnymi, przyglądając się współczesnym serialom. Autor skupia uwagę przede wszystkim na jednym z nich, Dead like me (Trup jak ja), który jest, jego zdaniem, przykładem nieoczywistości współczesnego spojrzenia na podstawowe dla Taylorowskiego rozumienia sekularyzacji rozróżnienia między immanencją a transcendencją. $\mathrm{Z}$ jednej strony estetyka serialu, którego główna bohaterka zamienia się w kogoś na kształt kostuchy towarzyszącej człowiekowi u schyłku życia, pomagającej mu przejść na „drugą stronę”, ma charakter ironiczny. Z drugiej jednak strony wielość motywów religijnych wyraźnie wskazuje na to, że wyobraźnia religijna współczesnego człowieka jest bardzo daleka od wyczerpania, a „epoka świecka", w której według Taylora żyjemy, nie jest wcale wolna od myślenia magicznego, choć procesy sekularyzacyjne bardzo głęboko zmieniły jego ramy.

Autorzy tego numeru „Prac Kulturoznawczych” reprezentują różne dyscypliny i podejścia do problematyki postsekularnej ${ }^{9}$, ich wypowiedzi nie składają się na jej systematyczną prezentację, stanowią raczej zachętę do kontynuacji rozważań i przesłankę kulturoznawczej konceptualizacji tego zagadnienia ${ }^{10}$.

\section{Michat Matlak, Dorota Wolska}

${ }^{9}$ Część tekstów była prezentowana na międzynarodowej konferencji Religion, (Post)Secularism, Culture. Transdisciplinary Perspective, zorganizowanej przez Laboratorium Humanistyki Współczesnej wrocławskiego Instytutu Kulturoznawstwa w 2015 r.

${ }^{10} \mathrm{~W}$ polskiej literaturze dyskusja na temat postsekularyzmu może nie jest zbyt zaawansowana, ale ma swoje miejsce. Teksty Habermasa wraz z komentarzami do nich zostały ogłoszone w miesięczniku „Znak” (2002, nr 9), specjalne „postsekularne” numery opublikowały pisma z zakresu nauk humanistycznych i społecznych: „Teksty Drugie” (2012, nr 1-2), „Pogranicza” (2011, nr 3), „Stan rzeczy” (2013, nr 5). Problematykę tę podejmowano między innymi w czasopiśmie „Logos i Ethos” (2014, nr 1) i „Frondzie” (prezentującej bardzo krytyczne względem postsekularyzmu stanowisko katolickich konserwatywnych intelektualistów). 